alike, the young wingless locusts, on emerging from the eggs in the spring or summer, feed voraciously and grow rapidly for two or three months, during which period they moult at intervals, finally developing wings and becoming adult. The adult insects fly about in swarms, which settle from time to time and devour the crops. The damage done by locusts is thus occasioned in the first instance by the young wingless insects, and afterwards by the winged individuals into which the young are transformed after a couple of months of steacly feeding.

In Rajputana and the Punjab in 1869 the flights were said to have come chiefly from the vast tract of sand hills (Teeburs) between the Runn of Kutch and Bhawulpore, and partly from the Suliman Range in Afghanistan. Locusts wer: reported as usually to be found in the autumn in the Teeburs, and it is thought that this tract is probably a permanent breeding-ground. The whole question, however, of the permanent breeding. grounds of these locusts is one that requires further investigation. The winged flights appeared throughout Central Rajputana in the latter part of the hot weather, and laid eggs which hatched as the rains set in; the old locusts dying after they had deposited their eggs. From these eggs were hatched young locusts which became full grown and acquired wings in August and September. The eggs laid by the original flights at the end of the hot weather were distributed throughnut the whole of Central Rajputana, and a vast amount of injury was done, the crops being damaged, in the first instance, by the young locusts before they acquired wings, and afterwards by the winged swarms which flew about the country and settled at intervals to eat what had escaped the ravages of the young wingless locusts.

In the Punjab, flights of locusts, from the Suliman Range, Afghanistan, appeared in the western border, in the end of April and in May. Eggs and young locusts were also found about this time near the hills in the sandy tracts of the same district. The flights seem generally to have moved from west to east, and by July to have spread themselves throughout the Punjab; but the laying of eggs and the hatching out of young went on, at least in the suuth-enst, throughout August and September.

In Bombay, locusts were noticed in May and June I882, in the south-west of the Presidency; but they attracted little attention, such swarms being annual visitors of the Kanarese forests, and neither in Kanara nor in Dharwar did they cause any material injury. With the setting in of the south.west monsoon, however, they spread in flights over the Presidency to the north and north-east, and early in the rains proceeded to lay their eggs and die. These eggs hatched in the end of July and beginning of August, and the young locusts did a large amount of damage, over a wide area, through the months of August and September. In the early part of October, with the setting in of the northeast monsoon, the young locusts, which had by this time acquired wings, took fight, and travelled with the prevailing wind in a south-westerly direction, doing some injury in the Poona Collectorate as they passed. They then struck the Western Ghâts, and spread slowly over the Konkan in November, and thence travelled into the Native States of Sawantvadi and the Kanara district. During the remainder of the cold season and the following hot weather (December I882, to the end of $\mathrm{M}$ iy 1883 ), the flights clung to the Ghâts, occasionally venturing inland into Belgaum, Dharwar, the Kolhapur State, and Satara, and devouring the spring crops in the Coast Dis'ricts, but ordinarily keeping in the vicinity of the hill ranges. With the commencement of the south-west monsoon, in the latter part of May 1883, the flights began to move in a north-easterly direction, as they had done the preceding year, but in larger numbers.

At the commencement of the rains they began to alight in vast numbers over an immense tract of country, comprising six Deccan Collectorates and three Coast Collectorates. They deposited their eggs and died; and early in August the young locusts batched out in countless numbers, but were apparently more backward, and possessed of less strength and stamina than were those of the previous year. The unusually heavy rainfall killed vast numbers of them in some parts of the country, and elsewhere the insects seemed stunted and feeble, and grew but slowly. They were destroyed in vast numbers by the vigorous measures initiated by Government officers, and were also said to be diseased and attacked by worms and other parasites. As late as November, the mass of the young locusts appeared still unable to fly, and made no general move, as they had done the year before, towards their permanent home in the south-west. The invasion was in fact at an end, and though swarms appeared in
Sawantwadi in $1883-84$, no further injury of a serious nature seems to have occurred.

The injury occasioned to the rain crops by the locusts was very conciderable, over a great portion of the Deccan and Konkan, both in 1882 and 1883 . But it was found, at the end of the invasion, that abundance of the cold weather crops had compensated to so great an extent for the injury done to the rain crops, that, on the whole, no very widespread suffering had arisen.

In 1878 , when the Madras Presidency was invaded, the young locusts began to appear in January; and were found in great numbers in different districts from then on till September and October, the earlier swarms being found in the west and south of the Presidency, and the later ones in the north and east. Winged locusts were first observed, in the end of March and beyinning of April, in the hills to the south-west (Wynaad and Nilgiri), where they may be supposed to breed permanently. Thence, aided by the south-west monsonn, they gradually worked their way over the Presidency to the east and north, finally disappearing about November and December.

The information hitherto obtained hardly justifies any very decided conclusion as to the life history of the locust. But it may be noticed that locusts were observed pairing in the Salem District, in the latter part of June, and also that the young locusts, which were found, in the early part of May, in the Udamalpet Taluk, were supposed to be the offspring of the large flights of winged locusts which had appeared in the preceding February in the same taluk. The connection hetween the autumn broods of locusts and those which appeared in the early part of the year has not been made out satisfactorily.

Mr. Cotes ends his paper with an account of the chief measures which have at different times been adopted in India against locusts, pointing out that, the locust of North-West India being distinct from that of South-West India, measures found useful in one invasion are not necessarily applicable in another.

\section{FIELD EXPERIMENTS ON WHEAT IN ITALY.}

PROF. GIGLIOLI, of the Agricultural College at Portici, a graduate of the Royal Agricultural College, Cirencester, has given to the Association of Proprietors and Farmers of Naples a voluminous and most carefully compiled Report on the results of the first year's experiments on wheat-growing at the experimental field of Suessola, about six kilometres fom Acerra. The field is on the estate of Count Francesco Spinelli, who generously lends it to the Association for experimental purposes. The district was celebrated in olden time for its fertility, but was afterwards long neglected on account of its marshy nature, and the land became sour and productive of disease. Now, again, drainage and improved cultivation have changed these marshes into some of the best land of a fertile district. The soil of the experimental field is easily worked, friable, and bears a good natural vegetation; no analysis of it, however, is furnished. Giglioli points out that it is in too high condition at present for comparative manuring experiments, but admirably suited for comparing different varieties of corn and different methods of sowing and culcivation, as by dibbling and the LoisWeedon system.

There are in all 102 plots devoted to trying the effects of different manures, each plot being about 43 square metres; I8 unmanured plots of a similar size devoted to different varieties of wheat; and 3 plots, each about twice the above-mentioned size, used for different methods of seeding and cultivation. Paths were made round each plot, the paths being at rather a lower level than the plots themselves The author discusses the question of large and small plots, but concluded that under the conditions obtaining, small plots were the best for use here.

On the IO2 manured plots, Scholey squarehead wheat was sown, with a great variety of manures-organic, nitrogenous, phosphatic, and potassic; but it was afterwards found this variety of wheat was, unfortunately, not well suited to the climate and to the general purpose of these experiments.

The 18 varieties experimented with, on the second series, incluced several well-known English varieties, such as Hallett's pedigree white and red wheats, Chiddam, golden drop, Hunter's $x$ "Resultati del Primo Anno di Esperimento sulle Varielà e sui Concimi del Frumento al Campo Sperimentale di Suessola nell
1887-88." By Italo Giglioli. Pp. 508 . (Naples, r889.) 
white and Victoria white, also some Hungarian wheats, besides Italian varieties.

It was found that the English varieties gave very poor results ; the squarehead was a very poor sample indeed, and it was unfortunate that it was used for the manuring experiments. The degeneration of English wheats during the first year is probably due to the great amount of transpiration taking place in this climate, especially during such a hot and dry summer as that of I888. Giglioli enters into an interesting discussion of this important physiological result.

The most productive wheat was a variety known as Noé, from the South of France, originally from Bessarabia-this yielded at the rate of 3485 kilograms per hectare; next in order were two Italian varieties, Rieti and Puglia grain, yielding at the rate of about 3150 kilograms per hectare. The Puglia wheat was the finest in quality of grain, but its yield of straw was very low.

The great importance of a careful selection of varieties is pointed out, and Giglioli is of opinion that much more good will be done by improving and selecting Italian varieties than by importing new varieties; which, if from colder countries, will probably not be able to stand the climate.

Incidentally, the experiments showed the great benefit of good cultivation and of surface draining, the plots being above the level of the surrounding paths, for the produce of the unmanured plots was double that of the neighbouring land under ordinary cultivation.

From the manuring experiments it was shown that farmyard manure gave fair results, but the season was unfavourable to the action of artificial manures, being much too dry. Of nitrogenous manures, acidified urine gave the best results, but nitrate of soda and sulphate of ammonia were often worse than useless. Phosphates had some good effect, and Thomas-Gilchrist slag was useful. Potash salts had no particular effect; the chloride seemed rather better than the sulphate.

The results of the manuring experiments, considering the great care and labour bestowed on them, must be disappointing ; but the soil is in too high condition for manures to show great effects, also the variety of grain sown was unsuitable to the climate, and the season was against manures, especially nitrogenous manures.

In this Report the details of the experiments are given in full, with the appearance of the plots at different dates, and the whole results tabulated in various ways in nearly a hundred tables. All the weighings at harvest were carried out under the personal superintendence of Prof. Giglioli, who evidently has spared neither time, trouble, nor health, in conducting these important researches. Already the results have yielded important information, especially on the suitability or the reverse of special varieties of wheat to the climate of Southern Italy, and with their continuance there can be no doubt that results most valuable to the Italian farmer on the cultivation and manuring of wheat will be obtained.

Whilst heartily congratulating Prof. Giglioliand the Agricultura Association of Naples on having inaugurated these experiments with the prospect of continuing them for some years, we cannot but think that their value would be greatly increased if the plots were larger; or, if this cannot be arranged with the appliances at command, if the experiments were always in duplicate, or preferably in triplicate, and this might be rendered possible by reducing the number of experiments on manures in future seasons.

E. K.

\section{SCIENTIFIC SERIALS.}

American Fournal of Science, February.-The magnetic field in the Jefferson Physical Laboratory, by R. W. Willson. One of the wings of this Laboratory in Harvard University has been constructed wholly without iron for the purpose of research, and the author has made a series of experiments to determine how far the end sought has been gained. He has found the magnitude of the disturbance which may arise in practice from such objects as stoves and iron pipes, and has made the interesting discovery that the brick piers of the building have a sufficient amount of free magnetism to produce quite an appreciable effect. - On Cretaceous plants from Martha's Vineyard, by David White. The author has studied a number of fossil plants collected at several localities and horizons in the Vineyard series for the purpose of solving the question as to the age of the underlying clays, lignites, and sands, of Martha's Vineyard. He concludes that the evidence from the fossil plants bespeaks an age decidedly Cretaceous, and probably Middle Cretaceous, for the terrane in which they were deposited.-Review of Dr. R. W. Ell's second report on the geolngy of a portion of the Province of Quebec, with additional notes on the "Quebec group," by Charles D. Walcott. The geological systems recognized in the area reported upon include the Devonian, Silurian, Cambro-Silurian (Ordovician), Cambrian, and pre-Cambrian.-Measurement by light-waves, by Albert A. Michelson. The telescope and microscope are compared with the refractometer, some remarkable analogies in their fundamental properties are pointed out, and a few cases in which the last-named instrument appears to possess a very important advantage over the others illustrated. Previous experiments have shown that the utmost attainable limit of accuracy of a setting of the cross-hair of a microscope on a fine ruled line was about two-millionths of an inch, whereas direct measurements of the length of a wave of green light emitted by incandescent mercury vapour, show that the average error in a setting was only about one ten-millionth of an inch. The method is also extended to angular and spectrometer measurements.-On lansfordite, nesquehonite, a new mineral, and pseudomorphs of nesquehonite after lansfordite, by F. A. Genth and S. L. Penfield. The authors have examined the crystallization of lansfordite $\left(3 \mathrm{MgCO}_{3} \cdot \mathrm{Mg}(\mathrm{OH})_{2} 2 \mathrm{I} \mathrm{H}_{2} \mathrm{O}\right)$, and another new mineral having the composition $\mathrm{MgCO}_{3} \cdot 3 \mathrm{H}_{2} \mathrm{O}$, which has been named nesquehonite. A crystallized artificial salt of the same composition is also described. - Weber's law of thermal radiation, by William Ferrel. An examination of Weber's new law, and a test of his formula by means of experimental results, in which the absolute rate of losing heat is determined from the observed rate of cooling of heated bodies of known thermal capacity, and the relative rate from the galvanometer needle of the thermopile. - Tracks of organic origin in rocks of the Animikie Group, by A. R. C. Selwyn. Traces of fossils, or what are supposed to be such, have been discovered in the Animikie rocks of Lake Superior. The fact is interesting and important, for, if the black Animikie shales represent the Lower Cambrian of the Atlantic border, the Paradoxides and Olenellus fauna will probably be found in them sooner or later.

IN the numbers of the Fournal of Botany for January and February, two important monographs are commenced-by $\mathrm{Mr}$. E. G. Baker, a synopsis of genera and species of Malveæ; and by Mr. G. Massee, a monograph of the genus Podaxis. This last genus of Fungi, Mr. Massee proposes to transfer, in consequence of the mode of formation of the spores, from the Gastromycetes, where it has hitherto been placed, to the Ascomycetes.

ThE Botanical Gazelte for October 1889 contains an in teresting summary of our present knowledge of protoplasm, by Prof. Goodale, in the form of an address to the Botanical Section of the meeting of the American Association for the Advancement of Science held at Toronto.

With the exception of an interesting paper by Prof. Mas salongo, descriptive of some curious instances of teratology in the floral and foliar organs, the number of the Nuovo Giornale Botanico Italiano for January is chiefly occupied by a report of the proceedings of the Italian Botanical Society. Among a number of short papers, is one on the fertilization of Dracunculus vulgaris, the most important insect agent in which is stated by Prof. Arcangeli to be Saprinus subnitidus; one on the fertiliza. tion of Arum pictum, by Prof. Martelli; and one on the development of the picnids of Fungi, by Prof. Baccarini.

\section{SOCIETIES AND ACADEMIES.}

\section{LONDON.}

Linnean Society, February 6.-Mr. Carruthers, F.R.S., President, in the chair.-Referring to an exhibition at a previous meeting, Prof. Stewart communicated some interesting observations on the habits of certain seaweed-covered crabs. He also made some remarks on the "pitchers" of Nepenthes Mastersiana, upon which criticism was offered by $\mathrm{Mr}$. Thomas Christy, Prof. Howes, and Mr. J. Murray.-Prof. G. E. Boulger exhibited a series of original water-colour drawings of animals and plants of the Falkland Islands.-Mr. W. H. Beeby exhibited some forms new to Britain of plants from Shetland.-Mr. C. B. Clarke, 